\title{
A METHODOLOGICAL JOURNEY THROUGH ETHNOGRAPHY
}

\author{
Seuwandhi B. Ranasinghe
}

\begin{abstract}
Reflecting on my commitment to an ethnographic study, this paper argues that an employment of ethnographic methods in a management control study can enable the marginalised to be heard and shared against postcolonial-patriarchal controls. It illustrates how my pre-fieldwork exposure shaped an in-fieldwork engagement into a post-fieldwork reflection until I realised my theoretical contribution: a management control perspective on the marginalised voices of female participants. The message here is that only such close engagements can unpack a multivocality of the researched, which positivistic research methods cannot achieve.
\end{abstract}

Keywords:

Ethnography, Management Control, postcolonial-patriarchal controls

\section{Introduction}

This paper is developed through the methodological encounters of my doctoral research. There, I aimed to explore how a group of marginalised females were controlled in an organisational setting, and how they could potentially influence the way in which they were controlled. Hence, I selected the case of tea plantations in Sri Lanka, and the marginalised group of women selected were the tea plucking women of Estate Tamil ethnicity. These women are marginalised due to repressions experienced through "multiple and overlapping patriarchies" that stem from "colonialism, race, caste, ethnicity, religion and cultural practices" (Jayawardena \& Kurian,2015,p.12). According to Jayawardena and Kurian (2015,p.13), plantation patriarchy is embedded in the way labour regimes are structured and how plantations are socially organised.

Considering the subject of the study, a marginalised group of women and the broad empirical question of control, an immersion into the intricacies of plantation controls and the female workers in that plantation was required. The broader research questions of the study could not be attained through a positivistic research methodology. Positivism through the presumption of 'objectivity' attempts to generalise and predict behaviour through mathematical and statistical tools. While there are some merits in this form of inquiry, positivism has been the object of critique by post-positivists and others since the middle of the twentieth century (Alvesson \& Sköldberg,2009,p.15) especially in the social sciences. Feminist researchers too critique the practice of positivism as "bad science" due to its exclusion of women from mainstream research (Hesse-Biber,2012, p.8), and also as it mimics patriarchy, privileging the researcher over the researched (Sprague \& Zimmerman,1993). They have over the years pushed for alternative methodologies that could better explore issues of women and other marginal groups.

\footnotetext{
${ }^{I}$ Department of Management and Organization Studies, University of Colombo, Sri Lanka. Currently Reading for PhD, Adam Smith Business School, University of Glasgow, UK Email: seuwandhi@gmail.com
} 
Incorporation of the lived experiences of women, their emotions and feelings into the knowledge-building process is important to feminist epistemology. However, there is no room for such forms of subjectivity in deploying positivistic methods. With postcolonial, post-structural and postmodern influences, feminist standpoint epistemology had to accommodate diversity of women's lived experiences and the interactions of race, ethnicity and class and other marginalised positions (Hesse-Biber, 2012, p.13). Hence feminist standpoint theory 'studies up' from the standpoint of the oppressed lives of women. "It starts from the everyday [experiences of women] to critically re-evaluate the adequacy of prevailing theory... as well as the dominant social institutions that such research tends to serve" (Harding,2012, p.49). From this perspective, research begins not from privileged disciplinary frameworks but from the lives of women who are being studied. This however, does not mean that the research process itself is not inspired by any theoretical or conceptual input and contain procedures to merely record voices of their subjects (Harding, 2012, p.54). Therefore a theoretical framework is important.

Reflexivity in feminist research questions the authority of knowledge claims of the researcher by exposing how power is exercised in the research process (Hesse-Biber \& Piatelli,2012). Hence from this perspective, it is a process where "researchers recognize, examine and understand how their social background, location, and assumptions affect their research practice" (Hesse-Biber,2012, p.17). Therefore, while being aware of one's own agenda affecting the research, reflexivity in feminist research requires researchers to be explicit about these subjectivities "at all points of the research process - from the selection of the research problem to the selection of methods and ways in which we analyse and interpret our findings" (Hesse-Biber, 2012, p.17).

Thus, a research design that enables the voices of marginalised to be shared in the research process along with reflexivity of the researcher, was deemed necessary for the research. A positivistic research design could not serve this purpose. Hence, ethnography was selected as the most suitable research design for this endeavour. Since "ethnography is about understanding human experience — how a particular community lives — by studying events, language, rituals, institutions, behaviors, artifacts, and interactions" (Cunliffe,2010, 227), my immersion into the field enabled "interacting with community members, observing, building relationships and participating in community life... [and in translating] that experience so that it is meaningful to the reader" (Cunliffe, 2010, p.228). Ethnography is "not about a method of data collection, but a way of engaging with the world around us... [shaped by our] assumptions about the way the world works and how it should be studied" (Cunliffe, 2010, p.233). Here, I use the term ethnography broadly. I acknowledge the diverse positions and directions ethnographers and anthropologists have taken and the debates they are engaging (Abu-Lughod, 1990; Alcadipani et al., 2015; Gilmore \& Kenny, 2015). However, I am reluctant to commit myself to a particular label such as feminist ethnography, reflexive ethnography and critical ethnography and so on, which I feel is a distraction to the deployment of this design flexibly, in telling the stories from the field. Since my subjective experiences are an intrinsic part of my work, reflexivity allowed me to acknowledge these subjectivities. Given my socio-cultural background and those of my participants, my approach to the field and negotiations with my participants had an inherent power gap. While I was not able to eliminate such a gap, being reflexive in my approach and in writing up my ethnography, I was more self-aware to expose such power imbalances. 
These reflexive accounts are presented henceforth. The paper is organised into five sections. Section 1 presents my pre-fieldwork reflections, followed by reflective accounts of my fieldwork and myself (in-fieldwork engagement) from the point of gaining access in Section 2, and entering the field, methods used and challenges encountered in Section 3. Section 4 presents my post-fieldwork reflections on how I theorised the outcomes of the ethnographic study, and Section 5 concludes the paper.

\section{Pre-fieldwork reflections}

With my interest in exploring issues of marginalised women in Sri Lanka, Estate Tamil females were considered, as they were a category of women who endure multiple forms of discrimination. Hence, they were the inspiration for the development of my research proposal. During this period, I was also engaged in another project with a colleague of mine in the University of Colombo, which inspired me to develop my research proposal connected to the plantation industry. There, we attempted to understand the plantation industry as a whole and the levels of poverty experienced by the plantation Tamil community. To meet this end, we met and discussed with few officials in the Sri Lanka Tea Board, a general manager of a tea brokering company operating in the Colombo Tea Auction, the General Manager of the Tea Small Holdings Development Authority, the CEO of a plantation company, and a trade union leader.

Due to the elite nature of most of the interviews conducted, it was apparent to me that their perspectives and concerns were economic. Profitability was a key concern and indicators of low labour productivity, high cost of labour and labour shortages were all problematic monsters that needed to be controlled. Although some were notably empathetic towards workers' issues and their levels of economic hardships, they claimed to be restricted by the low margins of the industry. The elite interviews, although provided an overall understanding of the industry, failed to adequately provide a flavour of workers' issues, especially females. Therefore, once my research proposal and studentship were accepted by the University of Glasgow, and before my arrival in Glasgow, I was encouraged to get a feel of plantation life, beyond the confines of the capital city I lived.

My initial discussion with the CEO of a plantation company gave me a brief understanding on some issues specific to female workers. However, my intention to visit a tea estate in this plantation was not fruitful as the CEO was out of the country at the time. Since I had little time remaining, I tried other avenues. This is when I was able to contact a retired Chairman of the JEDB . He shared his experiences of being a planter during pre-nationalisation period and then subsequently working for the State after plantations were nationalised. He also shared his experiences during the privatisation process of plantations during the early 1990s. His kindness and hospitality, inviting me to his house was extended beyond the interview when he introduced me to the CEO of Kelani Valley Plantation PLC. With its CEO's permission, I was directed to the Plantation Manager of Pedro Estate and given access to a visit, during the first week of September 2014.

There, I had a long conversation with the Plantation Manager who articulated his paternal instincts of ensuring the plantation is managed properly so that the adjacent worker population has a source of work and income. He shared his appreciation for the workers and mostly the 
female workers, who seem to be easier to manage than the male workers. Paralleling this interview with the interview I previously had with the CEO, I felt the extent to which the plantation management attempted to maintain traditional forms of controls. The hierarchy seemed to be still male dominated and the hierarchical structure of labour controls seemed to be more or less the same since colonial times. The nostalgia of the good old British days of plantation management, worker control and profitability could be read in between the lines. From these interviews, I felt that, although the British have been replaced by Sri Lankans, the one hundred-year-old established machines of controls were still being lubricated. Perhaps in different shapes, they still seemed to operate within the same old mechanics of control.

Once my talk with the manager was over, I was encouraged to go around the plantation, the factory, and talk to the workers there. A welfare officer accompanied me and introduced me to them. I had two interesting conversations with two different Tamil women. One was a tea plucker and the other was a caretaker of the plantation owned tea café adjacent to the factory. Both were young, though the former was relatively older with two young children and both shared their roots to plantation labour, where their parents had worked. The tea plucker, who spoke in excellent Sinhalese, told me that work in the plantation was relatively less strenuous than the work in the garment factory where she had worked before marriage. She told me that she likes it here. Her responses seem genuine, but I was not sure whether it was influenced by the welfare officer who was just next to us listening to our conversation.

In this brief interview I asked her about her aspirations for her children, whether she would encourage them to work in the plantation. She responded negatively. I felt that this response perhaps shows the contradictory nature of her genuine feelings of being in the plantation. Although she "likes it here" she doesn't seem to like her children being here! I asked her what they aspired to become. She mentioned that her daughter wants to be a teacher and her son wants to be a lawyer. I noticed that similar to most mothers who strive for social mobility in Sri Lanka, she was concerned about her children's education, and saw a future through them and for them, that she never had.

The second female I conversed was a young girl managing the company owned tea café. She served tea to us (the factory manager, the welfare officer, my husband and me), and she was not in the list of people the plantation manager intended that I talk to. It was the welfare officer who made the introductions to me. He was very proud to inform me that she is well educated and is empowered with managing this tea café on her own. I had a brief conversation with her in passing, and asked her how she came to be where she is with a tone of admiration. She talked about her achievements in education and training in various fields and was subsequently offered this job. She seemed to be beaming with confidence and an internal pride for achieving what others had not. I felt the impact of education and the potential it created for her and how it could perhaps be a significant liberator for women in this community.

Reflecting on the interviews and conversation among various parties in the plantation management, community, and others at this preliminary level, the following themes emerged to be significant to me. Firstly, remnants of colonial form of organisation structures and

\footnotetext{
${ }^{2}$ JEDB (Janatha Estate Development Board) was one of the two statutory Government organisations entrusted with managing plantations during the nationalisation period of plantations in the early seventies. Pedro Estate is located in the Nuwara Eliya District in the central highlands of Sri Lanka.
} 
management seem to be continuing with a local flavour infused with modern Western management practices. The management hierarchy seemed to be male dominated and paternalistic forms of control were observed. They saw themselves as agents entrusted with the responsibility of looking after a resident population, who work for them. One can draw parallels with these present attitudes to those held by the British planters as well. Since the Estate Tamil community was brought by the planters to these estates, the colonial administration made them their responsibility. Although it is clear that much has changed, it created an interest in seeing how and what these changes were in relation to management control.

Secondly, although none wanted to acknowledge explicitly, multiple forms of oppression of the female plantation worker was unmistakable. The silent presence of the patriarchal society and work climate perpetuating the levels of inequality and discrimination could be felt. However, for a deeper understanding of this, I understood the need to have a deep engagement with the females in this community.

Thirdly, labour shortage and females leaving the plantations was an issue that was repeated by many in the industry. An increased level of female education among this community was acknowledged by planters as a good prospect for their social mobility. Although politically incorrect and embarrassed to express in public, they felt this to be a detriment to the industry as they know it. I felt that it would be interesting to explore further whether these movements of females have any effects on the management control practices of the plantations. Hence these themes and concerns were embedded into the design of my study.

\section{Fieldwork and myself}

My pre-fieldwork reflections, helped design my fieldwork. This would be discussed in this section. I reflect on my fieldwork experience from the point of gaining access, to the way in which I entered my field, and conducted my fieldwork through ethnographic methods. Before I undertake this task, I need to be reflective about myself and my position in the research.

As a female born and raised in Sri Lanka, I was exposed to certain 'accepted truths' of patriarchy in culture, colonial legacy and its repercussions, and discriminations based on ethnicity, caste and class. However, I must acknowledge that I am from a relatively privileged family background, educated in an elite girls' school in the country and subsequently the premier university in Sri Lanka, where I am currently an academic. Therefore, although I see myself being a female, studying female issues in these plantations, my relative privileged background and education perhaps differentiates me from them. Apart from this difference, there is also the difference between our ethnicities. I belong to the majority Sinhalese ethnic group (around $74 \%$ of the Sri Lankan population); while the primary participants of my study belong to the minority Estate/Indian Tamil ethnic group (around 4\% of the population). Therefore, my position in the study is also shaped by the societal labels and the baggage I carry as a female in the Sri Lankan society. This in turn shaped the relationship I had with my research participants. Although I was in a way 'same' as them being a Sri Lankan female, I was also 'different' (Cunliffe \& Karunanayake,2013). Further, while I was an insider (a Sri Lankan 
born, aware of Sri Lankan culture, traditions, history and way of life etc.) I was also an outsider (new to the field, different ethnicity, education levels etc.) (Cunliffe and Karunanayake,2013).

\section{Access and ethical clearance}

To undertake this research with an ethnographic design required that I have access to the field, a tea plantation estate where I would have about six months of uninterrupted access to conduct my study. A formal approval of access was necessary prior to my field entry, to ensure that I am granted ethical clearance from the University of Glasgow to undertake this study.

Therefore, I approached the CEO of the plantation company. He was an acquaintance of my family, particularly my late father-in-law. I had a discussion with him regarding the tea plantation industry in Sri Lanka, its issues and prospects prior to my arrival in Glasgow. With contacts already established, and my subsequent communication with him after my arrival in Glasgow, he generously provided me formal approval to access the field.

With access granted to the field, the process of ethical clearance to conduct the research was initiated. Measures to deal with concerns of health and safety of the researcher while in the field, as well as the security of data and anonymising the research participants was articulated. Further, measures to recruit participants and gaining ethical consent from them to engage with my study was designed in this process. With granting of ethical approval in May of 2015, I left for my fieldwork on the last day of June with the intention of commencing fieldwork in July 2015 .

\section{Entering the field}

In July 2015, when I was attempting to make contacts with the CEO of the plantation company to start my fieldwork, I was confronted with an island wide plantation trade union strike in the form of a 'go slow'. The CEO informed me that he was busy with negotiations and meetings with the Ministry of Plantation Industries and I had no choice but to wait. During this time, I read newspaper articles on this issue. The wage negotiations were apparently in deadlock. On the one hand, the Collective Agreement which was in place till 31st March 2015 had lapsed, and thus, a new agreement needed to be signed. On the other hand, a parliamentary election was underway in August and the trade union power linked to national politics was trying to influence its plantation voter base. The demand was to increase daily wages to Rs.1,000, which is a $78 \%$ increase from the current wage structure. The regional plantation companies represented by the Planters' Association and Employers' Federation of Ceylon were calling it unreasonable, unless the wage increase is linked to productivity. The 'go slow' was called off on 17th July with the intervention of the new Prime Minister who requested both parties to hold this off till the end of the parliamentary elections. The heat of the dispute cooled after the swearing in of a new national government, but it was only in October 2016 that the new Collective Agreement was finally signed.

I was finally given a meeting with the CEO on 20th July and my fieldwork started immediately. The CEO was kind enough to provide access to the head office as well as the estate, which I refer to as UMA in this study. I was directed to an HR executive who then helped me meet the corporate management and other senior administrative staff of the head office and guided me with what I should expect during my fieldwork in UMA. I was given a vacant cubicle with a 
table and chair in the head office where I spent the next two weeks conducting interviews and conversations, writing daily ethnographic accounts and making sense of what I saw, heard and felt. Through the interviews and documentary analysis, I was getting an understanding of the management control systems in place. I observed the important role played by budgets and the emphasis given to budgets in monitoring all aspects of estate performance. With the lapse of almost two weeks, I requested to obtain approval to visit the Tea Auction to get an understanding of the final destination of the manufactured tea, and the prevailing market conditions of tea.

The Tea Auction was held at the Ceylon Chamber of Commerce. I was accompanied by the Marketing Manager and few other estate managers who came to witness how their products were fairing. I felt quite out of place when we entered the auctions as I was the only female in the room. Male dominance and male interest in the industry were quite apparent. Once the brokers started to speak, everybody started following a catalogue of the brokers as the bids were made very quickly. It took me sometime to figure out what they were actually saying. The brokers apparently had to sell seven items of tea under a minute. Through the conversations and observations at the auctions, I got a sense of the plight of the tea market. The prices were falling and many items remained unsold. There was hope that this crisis will end soon, however none was evident even after the end of my fieldwork in January 2016.

Once my work at the head office was completed, I made arrangements with the Estate Manager of UMA to start my fieldwork there. This re-location of fieldwork also needed a relocation of accommodation since I now had to be based in an area which was over $100 \mathrm{kms}$ away from my home in Colombo. UMA being in relative close proximity to the city of Ratnapura, it was selected since I already had established family links there. In addition to being based in a setting where I have some links, having selected an area where Sinhalese villages bordered the estate was advantageous, since the Estate Tamil community in these areas were known to be fluent in the Sinhalese language. Through the contacts of my extended family, I was able to find a boarding house of a young couple with two school going children, willing to provide accommodation to me during my period of fieldwork. Living just three kilometres away from UMA, I drove every morning for the next five months for my fieldwork .

The Estate Manager of UMA provided an unexpected level of access and support throughout my study. He introduced me to the Human Resource Officer (HRO), who was the most experienced welfare officer of the entire company, to help me with what I needed. From there on, I took residence in the welfare office of UMA and walked in the tea fields with her. The HRO cleared space for me in the welfare office, a chair and a table which I shared with a big photocopying machine. Comfortably placing my laptop, I typed-in the daily events that took place. I recorded what I heard, what I saw and my impressions based on the issues that were discussed by people who came to meet the HRO for their problems, observations during the field visits in all six divisions of UMA, subsequent interviews and casual conversations with people I met. Thus, reflexivity was embedded into my writing of ethnographic field notes.

The HRO was very popular with the workers and accompanying her during her field visits for the next two months helped gain familiarly and trust with my field participants. This was vital for me when I undertook the task of meeting them after this initial period, individually for 
interviews and conversations at the tea fields where they worked, at the estate office, or at their homes. However, as I anticipated in the design stage of the research, a power gap was evident between me and my female tea plucking participants. This was perhaps due to my difference from them in relation to my attire (jeans and t-shirt), my arrival to the estate driving a car, and the language of communication between me and the manager which was mostly in English. Fortunately this apparent power distance did not restrict any of my participants from expressing themselves freely to me. After a lapse of a month or so, I became a familiar face and linked with the welfare office of UMA.

During my fieldwork, the crisis in the tea industry was severely felt by the management and staff. The unsold stocks of tea piled up and the prices continued to fall. In one meeting, the manager gathered all field staff and welfare staff to declare that the past month's (October 2015) loss of the company was 400 million Rupees. He discussed the need to do something from their part to reduce the loss. I remembered a previous conversation with the manager few days prior to this where he told me that all managers of the company were getting a pay cut for that particular month. During this meeting with the staff, somebody talked about the possibility of selling tea in the weekend flea market in the town centre (the Pola). This resulted in a series of discussions on how such an endeavour would be done, marking the start of tea promotional campaigns in UMA. I participated in three such campaigns in three separate towns in the region. This opened doors for more access to staff enabling interviews and conversations in a relatively relaxed setting. These promotional campaigns continued even till the end of my fieldwork in January 2016.

\section{The fieldwork site and methods used}

Having accessed the field, I conducted my fieldwork during the period of July 2015 to January 2016. As I mentioned in the previous section, fieldwork was carried out in two main sites: the head office of the plantation company in Colombo; and UMA being one of its estates located in the Ratnapura District.

To guide my fieldwork, I prepared a data collection framework with schedules and rationales prior to entering the field (see Appendix 1). This enabled me to clarify what themes I should include and why, along with the broader concerns and questions I should ask. It further helped me iron out what method I could use to answer these questions and from whom I need to ask them. The broader themes were selected based on my conceptualisation of management control. With these parameters in mind (e.g. social, cultural, political, historical, and economic), and considering the patriarchal influence of management control, I designed questions to explore the perspectives of the 'controlled', in particular the perspectives of the female workers. Apart from these broader historical, political, economic, social and cultural influences on their lives, I also designed questions to capture their daily life in their public and private spaces.

This framework of questions was first put to the test as I entered my first field site. This was at the head office of the plantation company. As I mentioned in the previous section, the first two weeks (July 2015) of fieldwork were conducted at the head office in Colombo. There, I

\footnotetext{
${ }^{4}$ Except in few instances where I had to be in Colombo: scheduled interviews in Colombo; scheduled interviews of an NGO at Bogawanthalawa; scheduled supervisory meetings via Skype which needed better internet connection; personal family commitments such as a surgery of my mother.
} 
conducted formal interviews and documentary analysis. Interviews were conducted with the $\mathrm{CEO}$, corporate management, and other managerial and executive staff of the head office. Most interviews were recorded and in total approximately 11 hours of recorded and unrecorded interviews were conducted. A summary of the interview details are given in Table 1 below.

Table 1: Summary of interview details conducted at the head office

\begin{tabular}{|c|c|c|}
\hline Interviewees & Issues discussed & Time spent \\
\hline CEO & $\begin{array}{l}\text { About the company and his role as the CEO. On how } \\
\text { plantations are managed, operation of control } \\
\text { practices, issues of workers and staff. } \\
\text { Obtaining access for fieldwork in UMA }\end{array}$ & $\begin{array}{l}1.5 \text { hours } \\
\text { Discussions } \\
\text { over lunch }\end{array}$ \\
\hline $\begin{array}{l}\text { GM Quality } \\
\text { Assurance and } \\
\text { Marketing }\end{array}$ & $\begin{array}{l}\text { Quality control procedures and the production of tea. } \\
\text { General overview of the industry. } \\
\text { Impact of international markets. Operation of tea } \\
\text { auctions. }\end{array}$ & 1 hour \\
\hline GM Finance & $\begin{array}{l}\text { How management control technologies of the } \\
\text { organisation are made. The process of budgeting, its } \\
\text { controls from head office to estates and its impact. } \\
\text { Financial controls of the organisation. }\end{array}$ & 1.5 hour \\
\hline $\begin{array}{l}\text { M\&P Dept. } \\
\text { Manager } 1\end{array}$ & Budget guidelines and budgets & 2.5 hours \\
\hline $\begin{array}{l}\text { M\&P Dept. } \\
\text { Manager } 2\end{array}$ & Monitoring the budgets & 40 minutes \\
\hline $\begin{array}{l}\text { M\&P Dept. } \\
\text { Manager } 3\end{array}$ & $\begin{array}{l}\text { Estate controls and monitoring of work through } \\
\text { budgets, norms, standards and ratios by the head } \\
\text { office. }\end{array}$ & 1 hour \\
\hline $\begin{array}{l}\text { Admin Dep. } \\
\text { Manager }\end{array}$ & $\begin{array}{l}\text { Evolution of the company. Past experience of } \\
\text { operations during nationalised JEDB, SLSPC era until } \\
\text { privatisation. }\end{array}$ & 1 hour \\
\hline MIS Manager & $\begin{array}{l}\text { Budget guideline preparation and ERP system of the } \\
\text { company }\end{array}$ & 40 minutes \\
\hline HR- Executive & HR practices of the company & 44 minutes \\
\hline $\begin{array}{l}\text { Marketing } \\
\text { Secretary to } \\
\text { GM QA }\end{array}$ & Overall market for tea and its governance structure. & 25 minutes \\
\hline
\end{tabular}


In addition to these interviews, documents such as budgetary guidelines, budgets of individual estates, the Company's annual reports, collective agreements of the trade unions and other such agreements were recorded, photographed or photocopied and analysed. Further, observations were made at the Colombo Tea Auction to get an understanding of the prevailing tea market of the country.

Having completed two weeks of fieldwork at the head office, I commenced fieldwork at UMA from early August 2015 till early January 2016. From the first day of arriving in Sri Lanka for my fieldwork, I started maintaining an electronic diary. Once I started my fieldwork, I started writing daily entries of my field experiences in my ethnographic field notes. Unlike at the head office, at UMA, I did not attempt to initiate a single interview until the lapse of two months. I felt the need for my participants to be familiar and comfortable with me before such an attempt was made. Thus, the first two months at UMA was a period of observations and casual conversations.

Observations were made at the morning muster before the start of work, tea fields, at points of tea weighing, salary payments, Child Development Centres, line rooms of workers and residents, at Kovils, as well as the estate office and the welfare office among others. Summary of these observations are given in Table 2 below from the 83 full days of fieldwork at UMA.

Table 2: Summary of field observations at UMA

\begin{tabular}{|l|l|l|}
\hline Location & Observations made & Time spent \\
\hline Muster shed & $\begin{array}{l}\text { Operation of division of work, labour control } \\
\text { practices, performance of power (field staff and } \\
\text { estate management) }\end{array}$ & Around 5 days \\
\hline Tea fields & $\begin{array}{l}\text { Women workers reporting for work and daily } \\
\text { performance of tea plucking work. Work space } \\
\text { allocation by the Kangani to the pluckers, } \\
\text { standards of plucking. Operation of controls of } \\
\text { work. }\end{array}$ & $\begin{array}{l}\text { All divisions of } \\
\text { UMA (Div A, B, C, } \\
\text { D, E, F) around 25 } \\
\text { days }\end{array}$ \\
\hline Weighing centre & $\begin{array}{l}\text { Standard practices of weighing tea. Performance } \\
\text { of power (field staff). Meetings conducted by field } \\
\text { staff/estate management with pluckers and } \\
\text { sundry workers. Conduct of medical checks for } \\
\text { pluckers. }\end{array}$ & $\begin{array}{l}\text { Around 10 } \\
\text { occasions }\end{array}$ \\
\hline Divisional offices & $\begin{array}{l}\text { How budgetary records are maintained and } \\
\text { performed (plucking slips etc.); payments of } \\
\text { salaries; performance of power (field staff/estate } \\
\text { management) }\end{array}$ & Around 5 days \\
\hline Line rooms & $\begin{array}{l}\text { Living conditions; differentiation of status } \\
\text { between workers, staff and management. }\end{array}$ & $\begin{array}{l}\text { Around 4 } \\
\text { accasions } \\
\text { and patriarchal practices; ceremonies. }\end{array}$ \\
\hline Kovils & 3 occasions \\
\hline
\end{tabular}




\begin{tabular}{|l|l|l|}
\hline Estate office & $\begin{array}{l}\text { Labour days; performance of power by the office } \\
\text { staff/estate management over workers }\end{array}$ & $\begin{array}{l}\text { Entire duration of } \\
\text { fieldwork }\end{array}$ \\
\hline Welfare office & $\begin{array}{l}\text { Relationship between workers and the estate; } \\
\text { communication of work issues, family issues, } \\
\text { issues that needs mediation by the HRO to be } \\
\text { taken to the management. Monitoring of } \\
\text { budgetary targets with estate divisions. Welfare } \\
\text { practices. }\end{array}$ & $\begin{array}{l}\text { Entire duration of } \\
\text { fieldwork }\end{array}$ \\
\hline $\begin{array}{l}\text { Child } \\
\text { Development } \\
\text { Centres }\end{array}$ & $\begin{array}{l}\text { Maintaining records of plucking slips, colour card } \\
\text { systems etc. Operating as a crèche, looking after } \\
\text { workers' children. }\end{array}$ & Around 5 days \\
\hline $\begin{array}{l}\text { Estate } \\
\text { auditorium }\end{array}$ & $\begin{array}{l}\text { Ceremonies of UMA; staff meetings; trade union } \\
\text { meetings with estate management }\end{array}$ & 5 occasions \\
\hline
\end{tabular}

Since most aspects of plantation life cannot be verbalised by my participants, observations provided a richer and a more holistic understanding of data. It provided better interpretations in capturing non-verbal cues communicated through facial expressions, gestures, and emotional tones in their voices. Further, it enabled me to make sense of their visible daily routines at work, how they are being controlled, how they reacted to their work, their interactions and conversations with other working women and men as well as their superiors. These were recorded in my daily ethnographic field notes with imprints of my impressions, feelings, thoughts and reflections.

Selective interviews commenced in October. Interviews were considered to be formal conversations which were mostly recorded. I used the term interviews for these formal conversations and the term conversations to mean an informal conversation. Both these formal and informal conversations were recorded in my daily ethnographic field notes. However, there were many other informal conversations encountered during my fieldwork that was not significant enough to be recorded. Thus, these were not considered to be conversations for the purpose of the study. The questions in Appendix 1 which were mostly semi-structured were used as a guide rather flexibly. I allowed my interviewees to express themselves freely with the intention of capturing naturally occurring data. Although at times the participants went on a tangent for hours, subsequent analysis showed its importance. Interviews and conversations were conducted at all levels of the estate hierarchy. These are summarised in Table 3 below. 
Table 3: Summary of interviews and conversations conducted at UMA

\begin{tabular}{|c|c|c|c|}
\hline Participants & No & Time spent & Issues discussed \\
\hline $\begin{array}{l}\text { Regional } \\
\text { management } \\
\text { (Low country) }\end{array}$ & 2 & $\begin{array}{l}\text { Around } 5 \\
\text { hours and } \\
\text { other } \\
\text { unaccounted } \\
\text { hours of } \\
\text { conversation }\end{array}$ & $\begin{array}{l}\text { Management of plantations, issues and control } \\
\text { practices of the estate, staff and workers. Prior } \\
\text { experience of planting, recruitment strategies of } \\
\text { estate management, the conditions of the tea } \\
\text { market, future prospects. }\end{array}$ \\
\hline $\begin{array}{l}\text { Estate } \\
\text { management }\end{array}$ & 5 & $\begin{array}{l}\text { Around } 15 \\
\text { hours and } \\
\text { other } \\
\text { unaccounted } \\
\text { hours of } \\
\text { conversation }\end{array}$ & $\begin{array}{l}\text { Management control practices in the estate- } \\
\text { labour control practices, budgeting practices, } \\
\text { performance reviews, trade union activities, } \\
\text { general functioning and management of the } \\
\text { estate. Historical details of work experience as a } \\
\text { planter. }\end{array}$ \\
\hline Field staff & 7 & $\begin{array}{l}\text { Conversations } \\
\text { spanning the } \\
\text { entire duration } \\
\text { of fieldwork }\end{array}$ & $\begin{array}{l}\text { How the estate management enforce work } \\
\text { controls; effects of the budgets; the } \\
\text { implementation of budgets and monitoring work; } \\
\text { controlling workers; relationships maintained. }\end{array}$ \\
\hline Estate staff & 16 & $\begin{array}{l}\text { Conversations } \\
\text { spanning the } \\
\text { entire duration } \\
\text { of fieldwork }\end{array}$ & $\begin{array}{l}\text { Daily routine of work and controls that operate in } \\
\text { the estate }\end{array}$ \\
\hline Kanganies & 6 & $\begin{array}{l}\text { Conversations } \\
\text { spanning the } \\
\text { entire duration } \\
\text { of fieldwork }\end{array}$ & $\begin{array}{l}\text { History of work in the estate; detail experiences } \\
\text { of daily work and how they are being controlled; } \\
\text { how they control the workers; their relationships } \\
\text { with workers, field staff and management; role of } \\
\text { trade unions }\end{array}$ \\
\hline Pluckers & 23 & $\begin{array}{l}\text { Conversations } \\
\text { spanning the } \\
\text { entire duration } \\
\text { of fieldwork }\end{array}$ & $\begin{array}{l}\text { History of work in the estate; detail experiences } \\
\text { of work and how they are being controlled; how } \\
\text { they resolve their problems; difficulties in their } \\
\text { job- likes and dislikes; remuneration and } \\
\text { financial issues; involvement in trade union } \\
\text { activities; relationship with peers, supervisors } \\
\text { and management; family life and children; } \\
\text { culture and religion; future aspirations. }\end{array}$ \\
\hline Male workers & 5 & $\begin{array}{l}\text { Around } 5 \\
\text { hours and } \\
\text { unaccounted } \\
\text { hours of } \\
\text { conversation }\end{array}$ & $\begin{array}{l}\text { History of work in the estate; detailed experiences } \\
\text { of work and how they are being controlled; how } \\
\text { they resolve their problems; difficulties in their } \\
\text { job; remuneration and financial issues; } \\
\text { involvement in trade union activities; family. }\end{array}$ \\
\hline
\end{tabular}




\begin{tabular}{|l|l|l|l|}
\hline $\begin{array}{l}\text { Trade union } \\
\text { members and } \\
\text { leaders }\end{array}$ & 5 & 5 hours & $\begin{array}{l}\text { Involvement of trade unions in the operation of } \\
\text { the estate, relationship with management and } \\
\text { how they get things done, and their impact on } \\
\text { work and life of the workers. The role of female } \\
\text { trade union members and officials. }\end{array}$ \\
\hline $\begin{array}{l}\text { Retired } \\
\text { workers }\end{array}$ & 7 & $\begin{array}{l}\text { Around } 7 \\
\text { hours and } \\
\text { unaccounted } \\
\text { hours of } \\
\text { conversation }\end{array}$ & $\begin{array}{l}\text { Experiences of work in the estate; life history; } \\
\text { comparison of work and how controls operated in } \\
\text { the past with the present. }\end{array}$ \\
\hline $\begin{array}{l}\text { Educated } \\
\text { Tamil women }\end{array}$ & 5 & $\begin{array}{l}\text { Around 6 } \\
\text { hours and } \\
\text { unaccounted } \\
\text { hours of } \\
\text { conversation }\end{array}$ & $\begin{array}{l}\text { Experience of life in the estate; how they perceive } \\
\text { estate work, life and culture; their choices, } \\
\text { aspirations and reasons behind these. }\end{array}$ \\
\hline
\end{tabular}

Apart from the participants who worked in UMA, I also interviewed retired workers, workers who had resigned (former workers), educated Estate Tamil women whose parents are/were workers in UMA. In addition to the participants highlighted in Table 3, other social actors such as the Principal of the Primary School in Division A of UMA, a Samurdhi Official , PHDT officials, and NGO organisations such as PREDO and WERC were also interviewed to get a general understanding of the plantation sector, its people, work and issues. Details of all participants that I conducted interviews and conversations are given in Appendix 2.

During fieldwork at UMA, documentary analysis was also conducted. There, I observed old documents in the dusty storeroom of the estate. In addition to this, budgetary documents, annual accounts, minutes of meetings, colour cards, health reports, documents related to hectarage of cultivation, maps and others were observed and some were recorded and analysed. These are summarised in Table 4 below.

Table 4: Summary of documents observed at the head office and UMA

\begin{tabular}{|l|l|}
\hline Documents & Observations \\
\hline $\begin{array}{l}\text { Annual report of the } \\
\text { company }\end{array}$ & Financial position of the company \\
\hline Budget guidelines & $\begin{array}{l}\text { Guidelines on how the budget should be prepared by each } \\
\text { estate of the company. }\end{array}$ \\
\hline 2015 Budget of the company & $\begin{array}{l}\text { Annual budget categorised into months for each estate of } \\
\text { the company, and the two regions. This include details of } \\
\text { crop harvest, bought leaf, manufacturing, sales, expenses, } \\
\text { profitability etc. }\end{array}$ \\
\hline
\end{tabular}

5 Contacts with the Samurdhi official were made when I attended a Saraswathi Puja celebration at the Primary School.

6 Plantation Human Development Trust

7 Plantation Rural Education and Development Organisation located at Bogawanthalawa

8 Women's Education and Research Centre located in Colombo 


\begin{tabular}{|l|l|}
\hline Collective Agreement & $\begin{array}{l}\text { Major plantation trade unions, accepted standards of work } \\
\text { and pay, signed once in two years by the trade unions and } \\
\text { RPCs. }\end{array}$ \\
\hline Monthly accounts of UMA & $\begin{array}{l}\text { Details of crop harvest, production, revenue, expenses and } \\
\text { profitability for the month; compared to the budgeted } \\
\text { values for that month; estimated and actual 'to-date' values } \\
\text { considering the annual targets; compared to same month } \\
\text { last year. }\end{array}$ \\
\hline $\begin{array}{l}\text { Maps and hectarage } \\
\text { cultivation of UMA }\end{array}$ & $\begin{array}{l}\text { The geography of UMA and its 6 divisions. Cultivations of } \\
\text { crops, locations of kovils, line rooms and other buildings of } \\
\text { UMA. }\end{array}$ \\
\hline $\begin{array}{l}\text { Monthly family health } \\
\text { report }\end{array}$ & $\begin{array}{l}\text { Details of workers and eligible persons for employment in } \\
\text { the estate, estate population and families, details of } \\
\text { housing }\end{array}$ \\
\hline $\begin{array}{l}\text { Plucking slips, pluckers } \\
\text { turnover records, salary } \\
\text { slips, records of accidents, } \\
\text { health and safety records, } \\
\text { records of salary payments }\end{array}$ & $\begin{array}{l}\text { Practices that ensure management controls are maintained } \\
\text { and monitored. All financial dealings with workers } \\
\text { (including payment of salaries) required thumb } \\
\text { impressions. Signatures were not accepted- which was not } \\
\text { the same for other employee categories of UMA. }\end{array}$ \\
\hline $\begin{array}{l}\text { Personnel files of retired } \\
\text { Field Officers }\end{array}$ & $\begin{array}{l}\text { Control practices implemented by the estate management } \\
\text { for inability of reaching targets }\end{array}$ \\
\hline
\end{tabular}

Table 4: Summary of documents observed at the head office and UMA

Fieldwork in UMA concluded with the end of the first week of January 2016. The final two and a half weeks in January 2016 was allocated to retrieve important archival records of planation history and politics from libraries located in Colombo. For this, I selected libraries such as the National Library of Sri Lanka and libraries of the University of Colombo, National Institute of Plantation Management, Institute of Public Policy Sri Lanka, MARGA Institute, Centre for Poverty Analysis, Women's Education and Research Centre, and Social Scientists Association. These were recorded and some were photocopied to be brought back to Glasgow. In addition to these records, important books on plantations and the history of Sri Lanka were either purchased or photocopied and brought to Glasgow for further reference.

\section{Challenges encountered}

Prior to initiating my fieldwork, I dealt with instances of anxiety, anticipating about many issues in the field. Access was one such issue along with thoughts of whether my field participants would be corporative in answering my questions. Being a 
Sinhalese female, going into a vast landscape of fields to speak with women whose mother tongue is Tamil, was another such issue. The male dominated sphere and the nature of supervision and management created doubts whether it could be safe for me to spend months in the field as well. Regardless of my anxiety, fieldwork progressed successfully as I had initially planned. However, there were instances where I faced certain challenges.

Fieldwork consisted of extensive periods of walking from one field to another, and from one division to another in a mountainous terrain to meet and speak to tea plucking women and others. The deteriorated road network made it impossible to reach some of these locations, other than in a four-wheel drive vehicle, a motorbike or by foot. While I used my car to drive to divisions which had relatively good roads, in other instances, walking was the only possible option for me as well as the welfare staff of UMA. Challenges in reaching some divisions of UMA were more than others. Relating to this, I had noted the following in my ethnographic accounts on one such occasion.

'We started walking at about 8.30 a.m. passing the village to the estate land. We passed rubber trees, timber fields grown and the mountainous terrain surrounded by forests. It was a very difficult trek to walk. The roads were uneven which had rocks in them. It started to rain heavily as we walked and the roads became muddy. There were traces of tire tracks on the entire road up the mountain, and the centre of the muddy road was elevated than its sides where the grass had grown. We found it difficult to walk on the grass mound than the muddy two paths on the side because of the leaches. They were abundant on the grass. We carried our umbrellas to protect ourselves from the rain. I even wore a hat. But as we were walking, the leaches started to hang on to our feet and crawl up our legs. It was really difficult to remove them. As I reached my feet to remove the leaches holding my umbrella, I couldn't avoid being drenched in the rain. If the walk was short, this would not have been much of an issue. But we would have walked for about 5 hours until we left this particular division.'

While the walks in the tea fields were challenging, there were also challenges in driving to some divisions. In one instance, I was confronted with an angry man on a motorbike while I was driving on a narrow concrete road which had many bends, leading to a particular division. Both of us came face to face and applied brakes to stop our vehicles which would have otherwise resulted in a head on collision. I raised my right-hand palm gesturing an apology and continued to drive towards the division. Minutes later, I noticed the motorbike following me. Stopping my car and pulling my window down, I met with an angry man who mistook my gesture to mean "get lost!" I reassured him that my gesture meant to say, 'I am sorry'. He went on his way after being convinced. I came to understand how aggressive the Sinhalese village residents living adjacent to the estate tend to behave. I was cautioned to be careful in driving across particular areas towards UMA by management and staff of UMA. I was told that this area and its people were particularly notorious for taking 
the law into their hands, either in assaulting offending drivers (even though it was an accident) and/or burning the vehicle. One SD advised me that if, in the unlikely event I happen to knock a person while driving through this area, just leave the car and run! He was very serious in making this comment. I was very conscious about this throughout my fieldwork at UMA and fortunately did not experience any further incident.

As with any research, challenges in fieldwork are inevitable, but they have to be managed. In this case, being a native of the country, my understanding of the field, culture of residents and workers, as well as the ability to negotiate with the spoken language of the field, enabled me to manage these challenges. Further, having relatives in the region and extensive discussions with them regarding the location of the field prior to my arrival enabled me to anticipate some challenges. Although there were many hours spent walking in the field, as I highlighted at the outset, I was able to manage my time since I had already anticipated this at the design stage of the research.

Having discussed details of my field sites and fieldwork, the way in which I accessed my participants, the methods used and finally some challenges encountered, the next section elaborates my post-fieldwork reflections after I left Sri Lanka and returned to Glasgow.

\section{Post-fieldwork and theorising outcomes}

'In ethnography, the analysis of data is not a distinct stage of the research.... it begins in the pre-fieldwork phase, in the formulation and clarification of research problems, and continues through to the process of writing', (Hammersley \& Atkinson,2007, p.158). Therefore, an initial form of analysis was made prior to completion of my ethnographic fieldwork. This was shaped by my early reflections prior to fieldwork, the abstract theoretical lens of postcolonial feminism that carved the direction of the research during fieldwork, the daily ethnographic writing, Skype conversations with my three supervisors in Glasgow, and the weekly summary of writing reflections and insights of the past week.

This initial analysis was categorised into three broad themes: the historical macro story of plantations and controls over women in Sri Lanka; the micro story of management controls of women in the field; and the micro story of women's emancipatory possibilities. These themes were designed at the initial phase of the research and the observations, interviews and conversations, and other material that were collected focussed around these three themes. The ethnographic materials collected consisted of many hours of recorded interviews, over 2000 digital pictures, daily ethnographic field note entries amounting to over 183,000 words printed in 382 pages, files of photocopied archival records and company/estate documents. The magnitude of data collected therefore needed an efficient strategy to make sense of the data, hence, the initiation of the process of analysis.

Since there is no prescribed "formula or recipe for the analysis of ethnographic data" 
(Hammersley \& Atkinson, 2007, p.158) and theorising 'involve an iterative process in which ideas are used to make sense of data, and data are used to change our ideas' (Hammersley \& Atkinson,2007, p.161), rather than to start by transcribing all interviews recorded, I went back to my theory to rake out theoretical notions and themes to organise and make sense of my data, which was fresh in my mind. Although I went to the field having a theory in mind, it was an abstract understanding rather than a concrete theoretical framework. Having come back from the field with an added understanding of the stories and the phenomena observed, I re-read postcolonial theory and postcolonial feminist theory. With this, I started to re-write my theory chapter.

Having written the theory chapter, drawing on postcolonial feminist theoretical notions, I categorised my data using the three broad areas identified in the initial analysis since these were in line with the broader postcolonial feminist theoretical positions of macro and micro perspectives and connections as well as on controls and agency (Jayawardena,1986; Khan et al., 2007; Lewis \& Mills, 2003; Mohanty, 1995; Spivak, 1993; Suleri, 1993). Although I did not have a fine tuned theoretical framework at this stage, I organised my ethnographic data on these three themes. The analysis funnelled in from the three themes, to sub-themes, and then to codes (first level and second level). Reading through theory, I saw 'double colonisation' as a theme in my data. In particular, the concept of colonial domination and patriarchal domination of work practices was apparent and therefore was now considered as sub-themes in the first theme of double colonisation. As the second theme, management control practices were seen through forms of action control, results controls and cultural controls (Efferin \& Hopper,2007), which seemed a possible theme to capture the management control story. The third theme was identified as emancipation. Having identified these three broad themes, and subsequent sub-themes, I re-read my ethnographic writing. I then identified codes (and the page number) from my writing, and recorded them in the relevant theme (or sub-theme) identified. For instance, patriarchal domination which was a sub-theme of double colonisation, had codes of 'male violence', 'patriarchal culture', 'discriminations based on gender', and 'others'. For each of these first level codes, there were second level codes. For instance for the first level code of patriarchal culture, there were second level codes such as religion, ceremonies, and beliefs. Not all first level codes had second levels. These were emergent and flexibly used. With this initial identification of themes, sub-themes and coding, I initiated the writing process.

The empirical analysis of the study was shaped by the three broad themes identified at the outset. At each stage of writing the analysis, I traced the sub-themes and codes already identified in my ethnographic records, and re-visited the recorded interviews, transcriptions, and translated transcriptions. The analysis was written where I myself as the researcher was present, as an insider and an outsider (Cunliffe, 2011).

The first draft of the analysis took months to write. It was when I completed the first 
draft that I realised the theoretical notions that were appearing from my writings. Having realised this, I re-visited my theory. I used these theoretical notions to reframe my theory and develop my theoretical framework. The theoretical notions that emerged from my data were 'double colonisation', 'postcolonial transformations', 'subalternity', 'subaltern agency, and emancipation'. These were thus my theoretical contribution to management control from a perspective of the 'controlled', which is the perspective of marginalised females in the plantation. Theorising the outcomes was therefore an iterative process where there was a movement between theory and participants" accounts, "each informing the other" (Cunliffe, 2011, p.18).

\section{Conclusion}

In this paper, I narrated my reflection of pre-fieldwork that enabled me to anticipate my field site and design my research with realistic expectations. Ethnography was selected as my research design since the intention of the research was to broadly explore how a marginalised group of female workers were controlled, and how they could potentially influence the way in which they were controlled; and as this required an immersion into everyday experiences in plantations. I highlighted that a positivistic research design is inappropriate for this study, since it fails to answer my research questions and provide a space for multiple voices and subjectivities that capture intricate experiences of me and my participants. I declared my subjectivities and my subjective role in the research process differentiating me and my participants from an insider-outsider perspective. I presented my post-fieldwork reflections that enabled a theoretical contribution to management control from the perspective of marginalised females of my research.

Thus, the details of these reflective accounts of my pre-fieldwork, in-fieldwork and post-fieldwork were presented to demonstrate an ethnographic research design that could enable the researcher to immerse into the field and enable counter hegemonic voices to be heard and shared. It places the researcher at the centre of the research and enables negotiations with multiple voices of participants, especially the voices of the marginalised. This, therefore, is an argument against positivistic research that 'leave out' marginalised groups in their attempts of generalisation claims (Hesse-Biber, 2012, p.8). Feminist researchers in sociology for instance critique positivistic practice of 'detachment, both intellectual and emotional, from the daily work of keeping life going, from the people whose lives we study, and from popular political discourse. They take issue with the way we have organized the production of knowledge... They challenge a reliance on dichotomy and high levels of abstraction... [and] critique...the description of privileged masculine consciousness' (Sprague \& Kobrynowicz,1999, p.36). An ethnographic research design exposes these privileged patriarchal systems, especially from a feminist standpoint. As demonstrated, this is achieved through the engagement and sharing of marginalised voices of multiple research participants, which is unachievable by a positivistic research design. 


\begin{tabular}{|c|c|c|c|}
\hline \multirow{10}{*}{ 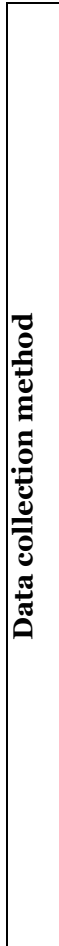 } & 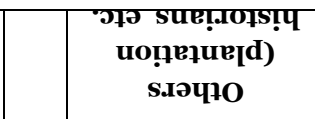 & $>$ & $>$ \\
\hline & 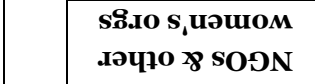 & & \\
\hline & 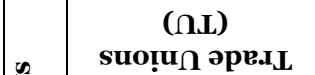 & & \\
\hline & 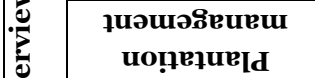 & & \\
\hline & 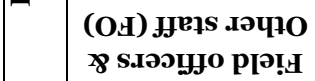 & & \\
\hline & 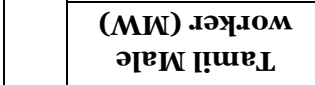 & & \\
\hline & 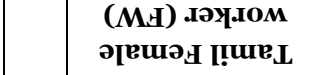 & & \\
\hline & \multicolumn{3}{|l|}{ (gO) SUO!̣en.IOSqO } \\
\hline & \multicolumn{3}{|l|}{ 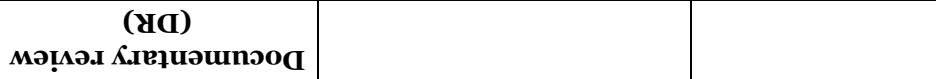 } \\
\hline & (GS) вұер K.repuosəs & $>$ & $>$ \\
\hline & 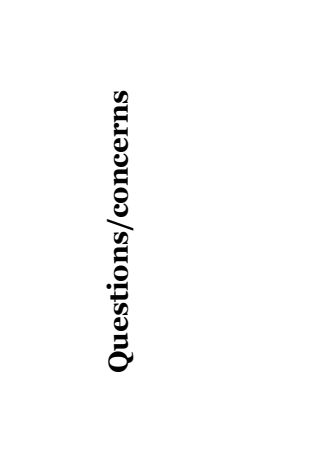 & 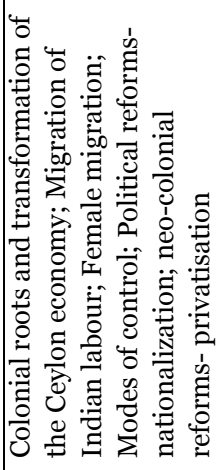 & 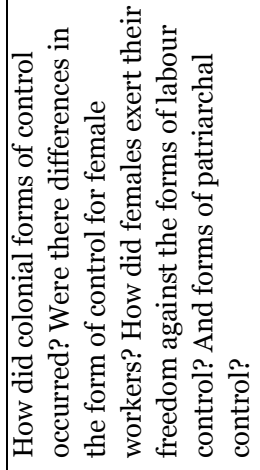 \\
\hline & 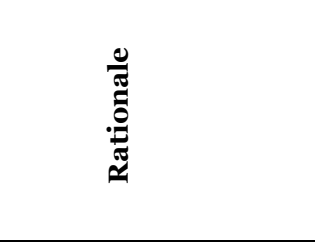 & 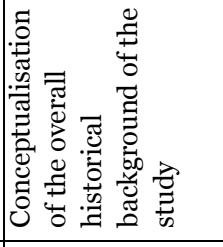 & 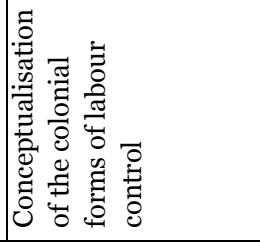 \\
\hline & 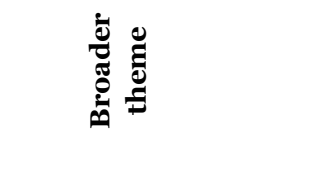 & 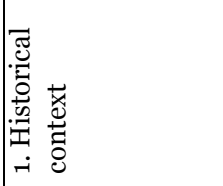 & \\
\hline
\end{tabular}




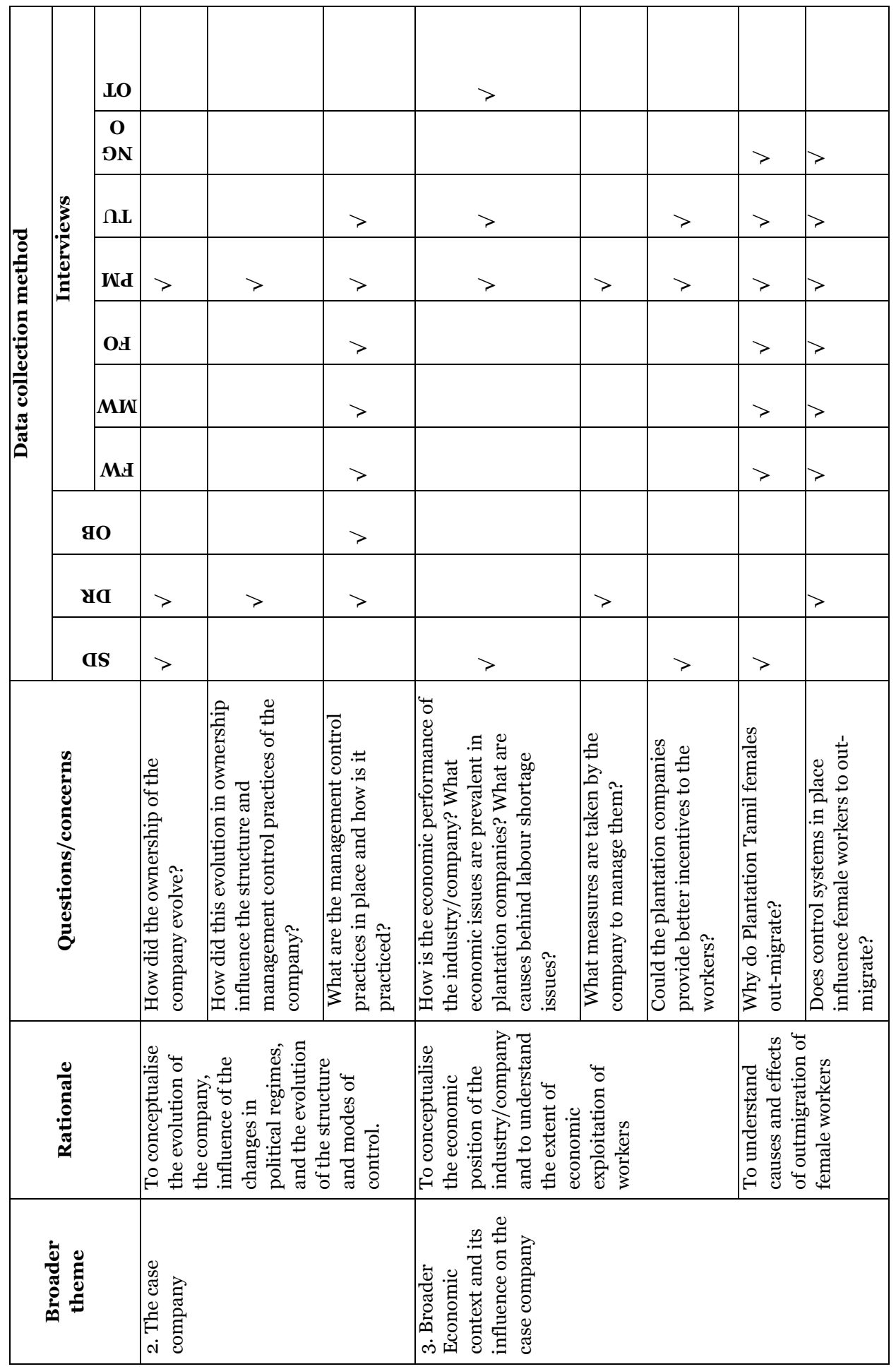




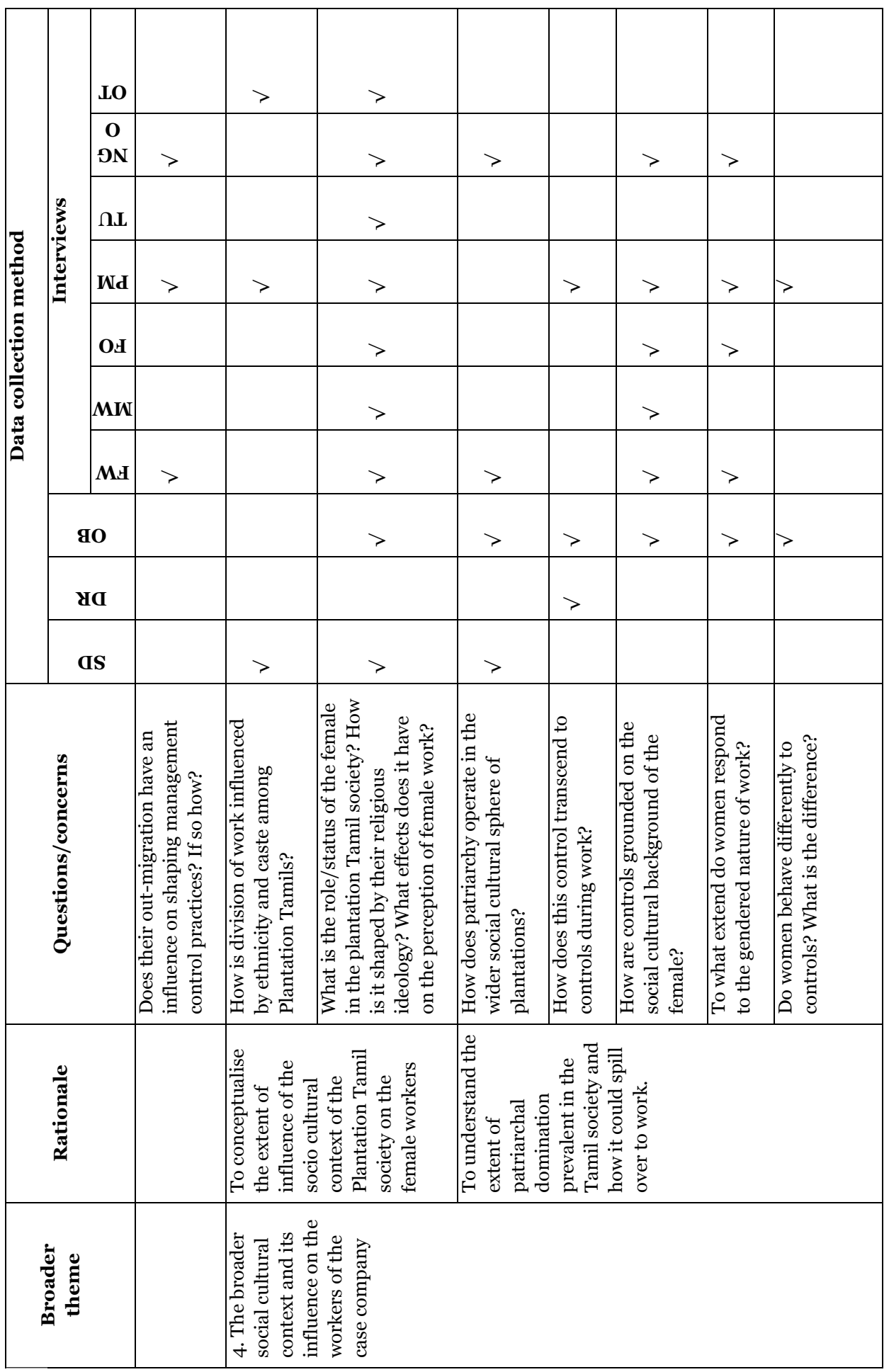




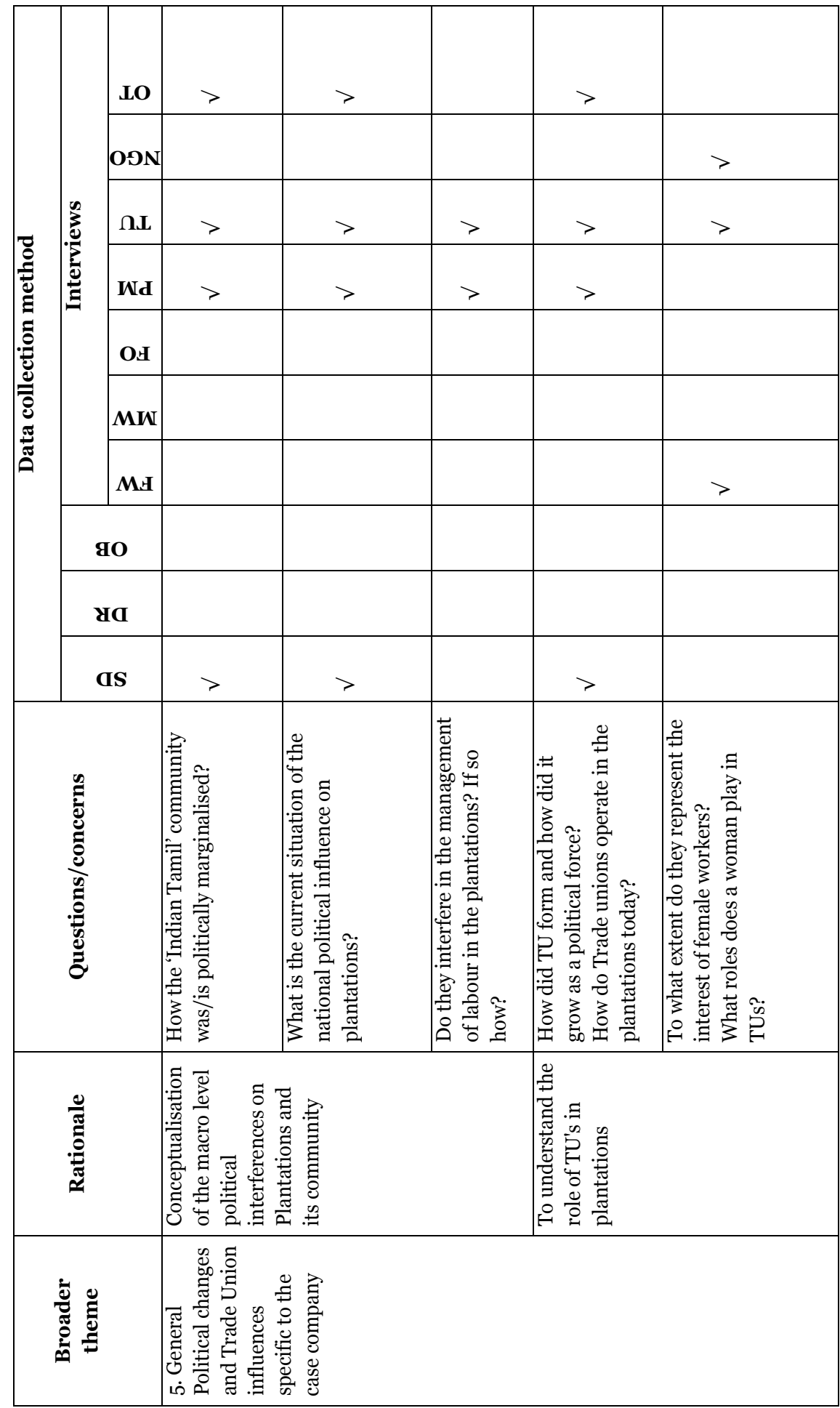




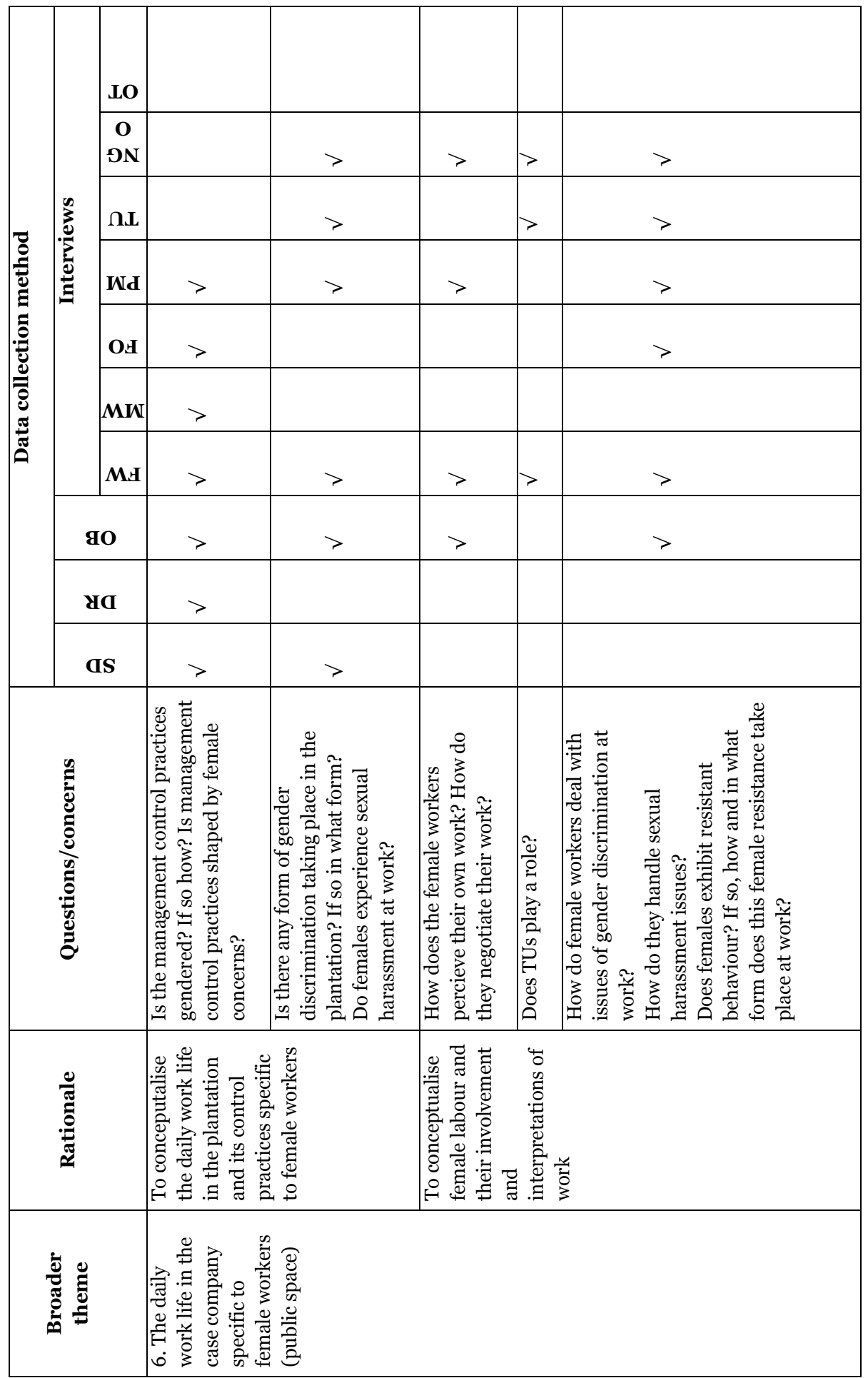




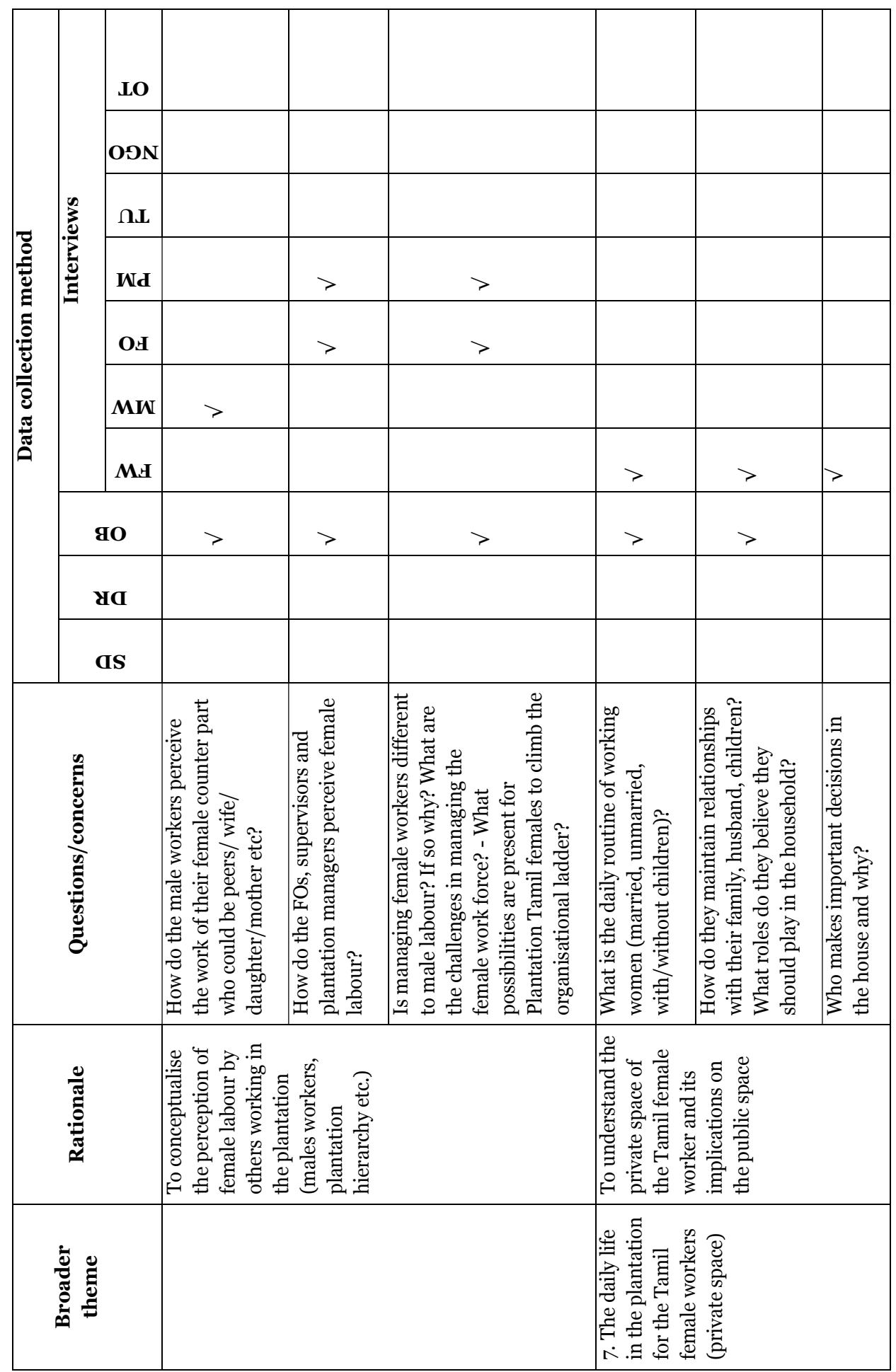




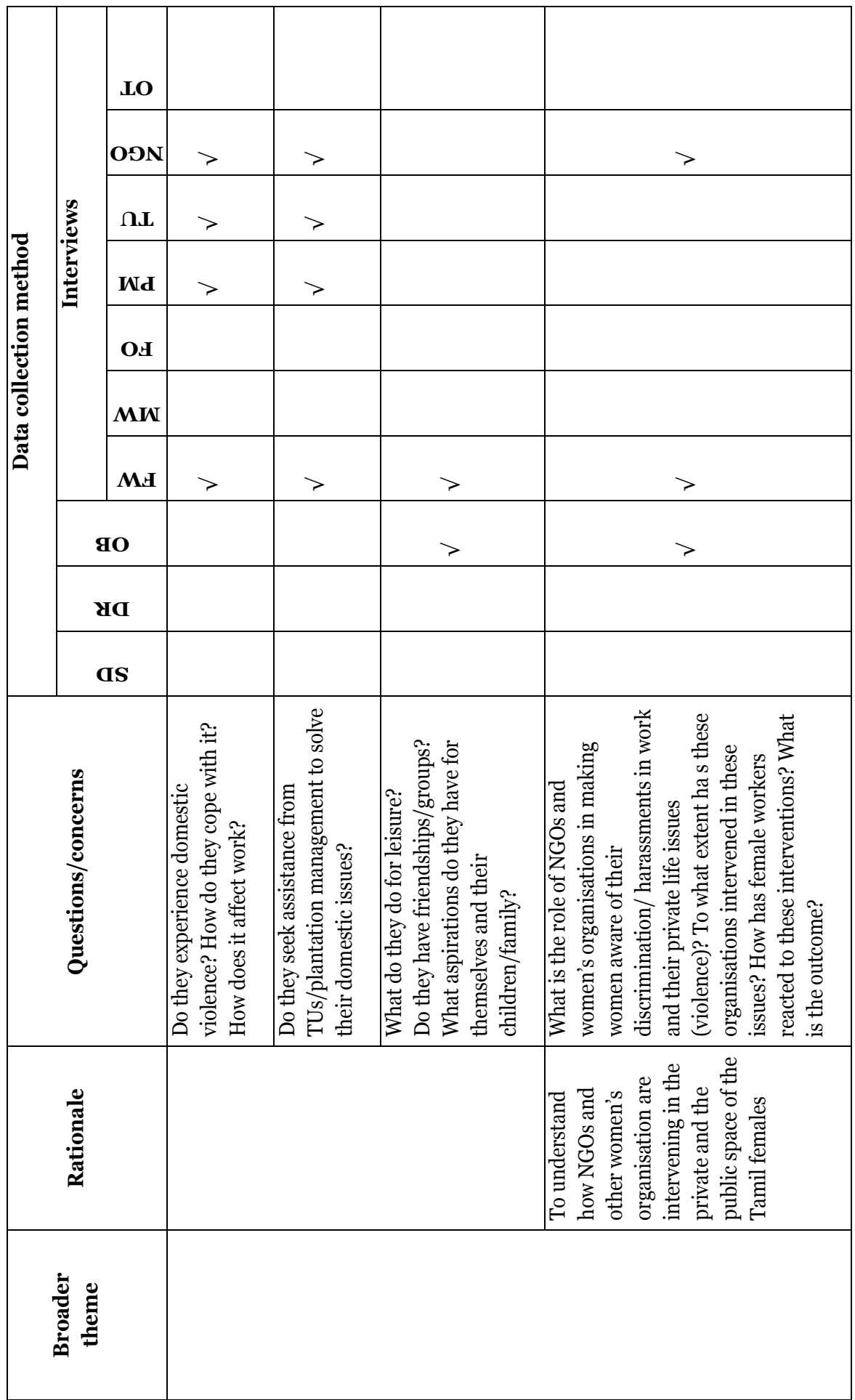


Appendix 2: Details of interviews and conversations conducted

\begin{tabular}{|c|c|c|}
\hline $\begin{array}{l}\text { Participant } \\
\text { category }\end{array}$ & Participants & $\begin{array}{c}\text { No. of } \\
\text { participants }\end{array}$ \\
\hline Head office & $\begin{array}{l}\text { CEO, Corporate management (GM Finance, } \\
\text { GM Quality Assurance and Marketing), and } \\
\text { other managerial staff (MIS manager, } \\
\text { marketing manager, Senior administrative } \\
\text { manager, other administrative managers from } \\
\text { M\&P Dept, HR executive and others) }\end{array}$ & 11 \\
\hline $\begin{array}{l}\text { Regional } \\
\text { management }\end{array}$ & DGM region and Manager Corporate Solutions & 2 \\
\hline Consultant & Visiting Agent of UMA ( a retired planter) & 1 \\
\hline $\begin{array}{l}\text { UMA } \\
\text { Estate management }\end{array}$ & $\begin{array}{l}\text { The Estate Manager, Deputy managers (2), } \\
\text { assistant manager (1), and the executive } \\
\text { administrative officer-CC (1) }\end{array}$ & 5 \\
\hline $\begin{array}{l}\text { Field supervisory } \\
\text { staff }\end{array}$ & FOs and AFOs & 7 \\
\hline Estate staff & $\begin{array}{l}\text { Welfare staff } \\
\text { Office staff } \\
\text { Factory staff } \\
\text { Medical staff (EMO and a midwife) }\end{array}$ & $\begin{array}{l}6 \\
4 \\
4 \\
2\end{array}$ \\
\hline Workers & $\begin{array}{l}\text { Tea pluckers (female) } \\
\text { Kanganies (include } 2 \text { females) } \\
\text { Sundry workers (male) }\end{array}$ & $\begin{array}{l}23 \\
6 \\
5\end{array}$ \\
\hline Trade union & $\begin{array}{l}\text { Trade union officials (include } 2 \text { workers already } \\
\text { accounted and other representatives) }\end{array}$ & 5 \\
\hline Retired workers & $\begin{array}{l}\text { Pluckers } \\
\text { Kangani }\end{array}$ & $\begin{array}{l}4 \\
3\end{array}$ \\
\hline Former workers & $\begin{array}{l}\text { Former female workers (resigned before } \\
\text { retirement) }\end{array}$ & 4 \\
\hline
\end{tabular}




\section{References}

Abu-Lughod, L. (1990) Can there be a feminist ethnography? Women \& Performance: a journal of feminist theory, 5 (1), 7-27.

Alcadipani, R., Westwood, R. \& Rosa, A. (2015) The politics of identity in organizational ethnographic research: Ethnicity and tropicalist intrusions. Human Relations, 68 (1), 79-106.

Alvesson, M. \& Sköldberg, K. (2009) Reflexive methodology, London, SAGE Publications Ltd.

Cunliffe, A. L. (2010) Retelling tales of the field: In search of organizational ethnography 20 years on. Organizational Research Methods, 13 (2), 224-239.

Cunliffe, A. L. (2011) Crafting qualitative research: Morgan and Smircich 30 years on. Organizational Research Methods, 14 (4), 647-673.

Cunliffe, A. L. \& Karunanayake, G. (2013) Working within Hyphen-Spaces in ethnographic research: Implications for research identities and practice.

Organizational Research Methods, 16 (3), 364-392.

Efferin, S. \& Hopper, T. (2007) Management control, culture and ethnicity in a Chinese Indonesian company. Accounting, Organizations and Society, 32 (3), 223-262.

Gilmore, S. \& Kenny, K. (2015) Work-worlds colliding: Self-reflexivity, power and emotion in organizational ethnography. Human Relations, 68 (1), 55-78.

Hammersley, M. \& Atkinson, P. (2007) Ethnography: Principles in practice, London, Routledge.

Harding, S. (2012) Feminist standpoints. In: Hesse-Biber, S. N. ed. London. 2nd ed., London, Sage Publications Ltd.

Hesse-Biber, S. N. (2012) Feminist research: Exploring, interrogating, and transforming the interconnections of epistemology, methodology and method. In: Hesse-Biber, S. N. ed. Handbook of feminist research: Theory and praxis. 2nd ed., London, Sage Publications Ltd.

Hesse-Biber, S. N. \& Piatelli, D. (2012) The feminist practice of hotistic reflexivity. In: Hesse-Biber, S. N. ed. Handbook of feminist research: Theory and praxis. 2nd ed., London, Sage Publications Ltd.

Jayawardena, K. (1986) Feminism and nationalism in the Third World, London, Zed Book. 
Jayawardena, K. \& Kurian, R. (2015) Class, patriarchy and ethnicity on Sri Lankan plantations: Two centuries of power and protest, New Delhi, India, Orient Black Swan.

Khan, K. B., Mcdonald, H., Baumbusch, J. L., Kirkham, S. R., Tan, E. \& Anderson, J. M. (2007) Taking up postcolonial feminism in the field: Working through a method. Women's Studies International Forum, 30 (3), 228-242.

Lewis, R. and Mills, S. (eds.) (2003) Feminist postcolonial theory: A reader,Edinburgh, Edinburgh University Press Ltd.

Mohanty, C. T. (1995) Under Western eyes: Feminist scholarship and colonial discourses. In: Ashcroft, B., Griffiths, G. \& Tiffin, H. eds. The post-colonial studies reader, London, Routledge.

Spivak, G. C. (1993) Can the subaltern speak? In: Williams, P. and Chrisman, L. eds. Colonial discourse and post-colonial theory, Essex, Pearson Education Limited.

Sprague, J. \& Kobrynowicz, D. (1999) A feminist epistemology. In: Chafetz, J. S. ed. Handbook of the sociology of gender, New York, Plenum

Sprague, J. \& Zimmerman, M. (1993) Overcoming dualisms: A feminist agenda for sociological methodology. In: England, P. ed. Theory on gende/feminism on theory, New York, Aldine DeGruyter.

Suleri, S. (1993) Woman skin deep: Feminism and the postcolonial condition In: Williams, P. and Chrisman, L. eds. Colonial discourse and post-colonial theory: A reader, Essex, Pearson Education Limited. 